\section{RESTARTING AGRICULTURE IN DEVASTATED EUROPE*}

\section{BY SIR JOHN RUSSELL, F.R.S.}

$\mathrm{N}^{\mathrm{H}}$ EVER before in the whole history of mankind could the people of Europe have had to endure such appalling sufferings as have befallen the occupied countries during the past three years. Poland, Belgium and Greece have suffered especially severely, but the other occupied countries only little less. Even the official rations are inadequate, often supplying only about half to two thirds our standard require. ments of calories, and in the case of Jews even less. But the official rations are by no means always forthcoming and the position would be desperate but for the operations of what the Germans call the "black market'-mainly a device for hoodwinking them. Recent refugees bring acounts of widespread and growing malnutrition and deficiency diseases, children crippled by lack of essential foods, adults suffering from acute forms of tuk erculosis, widespread malaria, typhus and other diseases: almost worse still, the populations crushed and made listless by hunger, and rapidly sinking to a condition when they can no longer take much part in rebuilding their shattered. lives.

Along with this increasing inability to recover, there has been an appalling destruction of the material means for recovery. The Germans have taken whatever they wanted, and as they are driven out of the different countries they will almost certainly destroy everything possible. Agriculture is largely thrown out of gear : the systems of farming and the rotations are upset. Transport, the twin sister of agriculture, is being utterly disorganized: ships, barges, railway engines, trucks and lorries are being destroyed as quickly as they can be found.

Further, there have been foreed deportations of masses of people who will want to be returned to their homes as soon as possible after the war : some eleven or twelve millions are said to be affected.

Modern Germany has certainly achieved the desolation on its borders that Caesar tells us the ancient Germans desired ("De bello Gallico", IV, $3,2)$.

A new factor has come into play with which it is by no means easy to deal. During the War, the art of propaganda has been developed to a remarkable degree, and we may be sure that after the War the Germans will make every effort to stir up trouble wherever there are difficulties of recovery. Even after the War of 1914-18, when the methods were crude and undeveloped, trouble was created in eastern Europe; this time the danger will be greater. We must face the fact that the post-war problems will be at least as difficult as those of the War itself.

The first need will be to send in food, and this must be done immediately the Germans are expelled from any region. The need will be so great that the utmost efficiency of distribution will be essential. The Nutrition Committee of the Allied Post-War Requirements Bureau under the chairmanship of Dr. E. F. Penrose, economic adviser at the American Embassy in London, has worked out suited basic rations. Another committee under Dr. Melville Mackenzie is working out methods to cope with the post-war diseases and epidemics.

* Royal Institution discourse delivered on March 5.
Steps will be taken to assure supplies of food, but they could not possibly continue indefinitely and it will be imperative to restart the agriculture of Europe at the earliest possible moment in order first to augment and later to replace the efforts of the relief organization.

The numerous agricultural problems involved are dealt with by the Agricultural Committee of the Inter-Allied Post-War Requirements Bureau (of the Ministry of Economic Warfare). This Committee includes representatives of all the occupied countries as well as of the Dominions and the United States, and I have the honour to preside.

\section{The Crops Needed}

From what is known of the food conditions in the occupied countries, it seems certain that the most serious shortage is in calories. Until these are available there is no point in supplying more vitamins; indeed, we are told that vitamins without calories might do more harm than good. Immediately possession of the land is obtained it will be necessary, therefore, to sow crops capable of yielding high calorie returns per acre: the easiest and quickest to grow are cereals and potatoes. Pulses will be almost equally necessary to make up deficiencies of protein, for meat is likely to be scarce. The requisite cultivation can be quickly done by tractors if they can be shipped across, but the seed cannot be quickly produced ; it must be saved from the crop of the preceding year. Provision of seed has, therefore, to be made beforehand. The position will be so serious that no avoidable risks can be taken; it will be' imperative that the seeds sent into any particular region shall, both as to crop and to variety, be suitable to the soils and the climate. These are largely out of our control and we have to adapt ourselves to them.

Now it so happens that in all the occupied countries the Germans have extended the growth of the calorie-producing crops, cereals and potatoes. If the War should end by the autumn of 1943 , the harvest of grain and potatoes would, so far as it remained intact, furnish seed for 1944, and much of the difficulty of calorie supply would thenceforward disappear. But if the War continues until the spring of 1944, much of the 1943 harvest will have been eaten or destroyed and the sowing programme will be more complicated. In any event, the supply of cereal and pulse seed must come mainly from the region itself; only in this way can on'e be sure of getting varieties suited to the conditions. In consequence, the first grain harvest after taking possession will have to be requisitioned by the Government of each country, and a corresponding amount of grain supplied for food. This will simplify enormously the difficulties of transport. Grain for seed must be selected with great care; the germinating capacity must be good ; the varieties must be properly chosen and delivered always to the right localities at the right time, and there must be no mixing of varieties en route. But for food grains none of these precautions are needed : one variety can serve as well as another, and germinating capacity is unimportant. There will, however, certainly be regions where war operations have led to destruction or consumption of what should have been saved for seed, or where normal supplies are unobtainable; for these some provision from outside sources must be made.

A list of minimum seed requirements has been 
drawn up, based on the assumption that requisitioning can supply 90 per cent of the seed grain. It includes more than half a million tons of grain seed, mostly wheat and rye-this is only a tenth of the actual requirement-also 11,000 tons of pulse seed, 425,000 tons of potato seed, 20,000 tons of seed for fodder crops, and 27,000 tons of lupins and seradella seed, chiefly for green manuring though some is used for fodder; the weight of vegetable seed required is much smaller though its importance is very great. The total is more than a million tons. The shortages are likely to be very unequal : France is normally an exporter of seed and may lack little beyond wheat and potato seed. Greece, on the other hand, will probably be very short of all seed, of wheat, pulses, potatoes and vegetable and fodder crops. Poland is likely to lack rye, wheat and other cereal and pulse seed, but perhaps not potato or sugar beet seed, though seed of beetroot-so important in Polish cookery-will probably be needed. Czechoslovakia and Jugoslavia will probably lack every kind of seed, and Belgium also. Denmark and the Netherlands may be better off.

How can all these demands be met? It is, of course, imperative that varieties be suitable : sources of supply must be selected where the climatic conditions are similar to those of the regions for which the seed is intended. Something can, let us hope, be drawn from Germany, Italy and Hungary, which normally supplied seeds to neighbouring countries. Sweden, a producer of high-quality pedigree cereal seed, could supply Norway, Denmark and Poland; Great Britain can furnish wheat, oat and potato seed to Holland, Belgium, France and parts of Poland, also some spring-sown cereal seeds to Norway, and seeds of vegetables and fodder crops to various countries; North Africa could supply wheat to France and Greece; Turkey could supply wheat, barley and oat seed to Greece.

Potato seed is likely to cause trouble: the only countries with any to spare may be the United Kingdom, perhaps also the Netherlands and Poland, unless the hunger in that tortured country becomes too great. But the storage of potato seed needs care, and disease may spread in the Continental stocks, in which case the United Kingdom becomes the sole reserve.

In all probability it will be necessary to go farther afield. North America can do something, but its climatic regions differ so greatly from those of Europe that only few similar regions can be found for winter crops, though it might do better for spring crops. Eastern Canada could supply autumn wheat seed to Poland, spring oats to Czechoslovakia, peas to Norway, also peas and haricots to Greece. The United States could provide some cereal, fodder crop and pulse seed to Czechoslovakia and. Jugoslavia, and perhaps most of the Greek requirements. The Argentine could also supply wheat seed to Greece. There still remain difficult questions of transport; and, of course, the tragedy is that Europe was normally not merely self-sufficing for most seeds, but also had a large export trade.

\section{Livestock Problems}

Much more difficult problems will be presented by livestock. Before the War, Europe was comfortably well off for livestock-farm animals, without counting poultry, were nearly as numerous as human beings. In the occupied countries there were in the aggregate
44 million cattle, 34 million sheep, 10 million goats, 27 million pigs, and 10 million horses; 125 million in all for a human population of 137 millions. The numbers of cattle and of pigs generally ran in the same order as the numbers of human population : in most countries, as in the average of all, there was one head of cattle to three or four human beings, and one pig to about five : Denmark had more, having a very large export of dairy produce and bacon, and Greece had less but made up with sheep and goats. The numbers in Great Britain corresponded with these when allowance is made for the fact that we provided only about 40 per cent or less of our food. This similarity of cattle population would not mean similar standards of life. Western European countries imported far more feeding stuffs than Poland and the Balkan countries, and so had a much larger margin for themselves, even after the export demands were satisfied.

The population of horses was not quite in the same order as the human population or the numbers of cattle and pigs. Poland stood highest, partly because of the great importance the Government attached to cavalry, partly also because the peasants much loved horses, and always aspired to be able to drive to church on Sundays in a two-horse and not a one-horse vehicle, with two good horses, not poor ones. Jugoslavia used many horses for transport; Danish farmers loved horses and preferred them to tractors even though the tractors might work more quickly, while Greece used horses for transport and in addition had a considerable number of mules and donkeys.

Cattle are of special importance because they supply three vital necessities : milk, meat and motive power on the farm, but they do not all serve all these purposes. The breeds of cattle in Europe fall into two main groups: the peasant types and the good estate types. The peasant types have been evolved by survival: they are hardy and can live on very rough food and they are fairly resistant to tubercle and to insect-borne diseases. They usually have to serve several purposes : milk, reproduction and work during their active life, and in later life for meat and for leather. These peasant types are very localized: the Polish red cattle, for example, are scarcely to be found outside Poland, though a few, such as the Simonthal, are fairly widespread in Europe; practically none, however, is found outside Europe.

The good-estate types of cattle, on the other hand, are much more specialized, and have been evolved by careful selection, usually for one purpose only, or at most combining only meat and milk production. They give more milk than the peasant types though it may be less rich in butter-fat; the meat types also produce more meat; but they are never used for work. They are less hardy than the peasant sorts, usually more susceptible to tubercle and insect-borne attacks, and more exacting in the matter of food. Certain breeds have spread widely : the Frieslands, for example, are now found all over Europe, but usually on good-sized farms.

Sheep also serve several purposes : milk, reproduction, wool and meat, though even the peasant sorts do not work. But sheep are not closely related to the human population. They occur in high densities in two regions: Great Britain (which is easily first), and south-eastern Europe. The explanation is that sheep fit in very well with intensive cropping systems as adopted in Great Britain; but 
they are also more suited than other animals to the poor conditions of hill countries.

It is impossible to form any close estimate of the present numbers of livestock, but piecing together the fragmentary information available it appears that by the middle of last year the loss of cattle alone was probably not less than eleven million head -nearly one and a half times the total cattle population of the United Kingdom, or a quarter of the prewar cattle population. The losses had apparently fallen heaviest on Greece and Poland ; so far as could be judged, their numbers were down by about a third or a half. Denmark appeared to have suffered less than most of the others.

It is certain that the position has deteriorated a good deal since the middle of last year. Moreover, these figures, grave as they are, do not tell the whole story. It is the best animals that have gone. Many of the survivors are immature and consequently of less production value; they are not as well-fed as in peace-time and so the yields of milk and of meat have fallen more than is indicated by the fall in numbers. The fall in milk yield has been estimated at 35 per cent; that is, some 3,500 million gallonsmore than two and a half times the total production of England and Wales. The loss of sheep has been as great as the loss of cattle over the whole area; that is, about 11 million head; but it has fallen with peculiar harshness on the people of Greece and of Jugoslavia, where sheep were important as the source of milk.

The loss of pigs has been even heavier : by the middle of last year the total numbers in the occupied countries were down by at least 12 million--half the pre-war total-and the fall is certain to be greater now. Denmark, the Netherlands, Belgium and Luxembourg appear to have suffered worst. In most of the occupied countries pigs were the chief source of animal fat; their heavy fall in numbers means a drastic curtailment of calorie supplies.

The reduction in horse population has also been severe owing to heavy requisitioning for the German Army: By the middle of last year, the numbers were estimated down by about three or four million, that is, some $35-40$ per cent over the whole occupied region, but the Netherlands had suffered even greater loss, which means, of course, that the working of the farms has become correspondingly more difficult.

Poultry have suffered most of all; by the middle of last year the numbers were only about one quarter the normal, and the position is certainly worse now.

Restoration of the animal population will be slow and laborious, and cannot be attempted until food supplies are in sight : one of the mistakes made after the War of 1914-18 was to send animals before the food was ready for them, and so they simply had to be slaughtered. After food for the animals is assured, milch cattle must be among the first to be increased so as to start making up the very great shortage of milk. Something can be done by supplying more and better food to the surviving animals, for the output of milk increases, up to a point, with the increase in food supply. But this will not suffice. Importation of live animals would be a solution if it were practicable. There may, and we hope there will, be a certain amount of disgorgement from Germany both of pedigree and of utility animals that have been taken from the occupied countries. Hungary may be able to supply one of the peasant breeds, the Simonthal, which is used both in Czechoslovakia and Jugoslavia; Switzerland also may have some to spare and also another peasant breed, Montafon. It is improbable that much of anything movable will remain in Italy after the War, but two Italian breeds, Reggio and Romania, would be useful in Greece. Movements of cattle within the continent of Europe would be easier than importation from overseas. But it seems unlikely that we can reckon on much from Europe; any immediate increase in Europe's cattle population could come only from overseas. Peasant breeds are unobtainable in this way, but good useful Friesians and Ayrshires could be drawn from Canada and the United States; it is not possible to say how many, but even if the figure is put at one million-which would be high-it still replaces only a fraction of the total loss. But there is the further difficulty of transport. A cargo boat of the ordinary $5,000-8,000$ ton size could carry some 600 or 700 head of cattle, so that more than 1,500 journeys would be needed to transport our hypothetical million animals.

It seems safe to assume, therefore, that the reestablishment of the herds of milking cattle must come mainly from natural increase. But that is a very slow business : it takes at least two years to produce a new dairy cow, and only half the calves born are females. Cows vary widely in their capacity to yield milk, and it is well known that this quality is derived from the bull. So, from the outset, bulls with a good record of high-yielding daughters should be selected for replenishing the herds: the United Kingdom could supply some of these. Fortunately, the modern method of artificial insemination enables good bulls to be used very economically and to produce numbers of good-yielding calves from animals they have never seen : the bulls can be kept at control stations and the semen distributed by motor-car or by aeroplane over a large number of farms. In view of its importance, courses of instruction in the method have been arranged and attended by veterinarians selected by the different occupied countries, so that they can organize its wide adoption directly they get home. It would be possible to keep the bulls in Great Britain and dispatch the semen by air to the different centres, but it would be more convenient to establish centres in the different countries and to keep carefully selected bulls there. This would, of course, involve importation of the live animals, for which the necessary priority would have to be arranged.

But however carefully it is done, it seems unlikely that the cattle population of Europe can be restored in less than about six years. During the whole of this time, dried milk and other dairy produce will have to be sent into Europe.

The restoration of the horse population will take much longer because the difficulties are greater. Germany could restore any requisitioned horses that survive: the United States could probably supply Percherons if transport was available. Artificial insemination is of much less help than for cattle. Little addition to the total numbers can be expected during the first five years after the War, and full restoration to pre-war numbers may take some fifteen or sixteen years. During the first years it will be imperative to do much eultivation by tractor, though, as every farmer knows, the tractor does not altogether replace the horse for general farm work.

Under good conditions the sheep population should 
recover more rapidly than the cattle, but in poor and hard conditions such as will certainly obtain in southeastern Europe, recovery is bound to be slow ; it has been estimated as at least nine years.

Pigs, however, multiply much more quickly; a good sow can produce and rear ten or fifteen piglets in a year; in spite of the drastic reduction we need not assume more than two years as the time needed for restoration to pre-war numbers. Not only are pigs by far the most prolific of all the larger farm. animals, but they are also the most economical in their conversion of food into meat and fat, both of which will be urgently needed in Europe after the War. The case for the pig would be irresistible but for the unfortunate circumstance that, of all the animals on the farm, pigs are most like ourselves in food requirements : they take grain, potatoes, skim milk, fish and meat; they thus stand in sharp contrast with sheep and cattle, which take grass, straw and other coarse fodders of no use to us. So when human food is scarce pigs are not encouraged, or at least not beyond what can be fed on waste materials unfit for human consumption.

The same difficulty arises in the case of poultry, which are even more prolific than pigs, for under good management one hen may produce large num bers of chickens in a year. But again the food required is largely the same as for human beings, and so in spite of their value as producers of highclass protein, and tragically enough, in spite of the great need of high-class protein, it will not be possible greatly to encourage poultry-keeping, at any rate until the human food position becomes elearer. It will, however, be essential to furnish the peasants with some pigs and poultry as early as possible, so as to ensure speedy re-establishment of their holdings and full utilization of any waste material.

Certain administrative actions will facilitate matters. Immediately the Germans are expelled from any region it will be necessary strictly to control the slaughter of animals and to forbid the slaughter of female animals suitable for breeding and milking, and some at least of the working bullocks; if possible, however, bringing in some compensating amount of meat. The distribution of feeding stuffs will need to be regulated, and the veterinary services must be put into operation.

The reduction of livestock has greatly decreased the production of farmyard manure, and this has been intensified by the shortage of fertilizers, especially of phosphates. Immediately the Governments secure possession of their lands, this difficult problem of restoring fertility will need attention. Lupins and seradella can in certain regions be grown as green manure if seed is obtainable. The supply of fertilizers is likely to present many difficult problems because of their localized distribution. Phosphates are obtained mostly from North Africa, and potash from Germany and Alsace; nitrogen-fixing factories are more widespread, but their present products are not very suitable as fertilizers.

Lastly there remains the extremely difficult problem of re-settling on the land the enormous number of people-estimated at some 11-12 millions-taken or deported from the occupied countries. This, however, I do not propose to discuss.

The immediate starting up of agriculture is only a small part of the task. Agriculture is a long. term business; the farmer must know not only what he is to grow this year but also what the year after, and the year after that. So it is neces- sary to think ahead beyond the 'first-aid period' and to decide what is to be the object of the agriculture. In the first year it must produce calories. But is that to continue permanently? There are two purposes at which European agriculture might aim : highest standard of nutrition for the people; or maximum degree of self-sufficiency for the country or group of countries. Although we did not deliberately aim at it, we in the United Kingdom achieved the highest standard of nutrition in Europe but the lowest degree of self-sufficiency. Germany, on the other hand, achieved a high standard of self-sufficiency but a considerably lower level of nutrition. The British dietary was rich and varied and required large areas of land for its production: on English yields no less than 1.6 acres, of which beef alone accounted for nearly half; but much of our food was imported from countries of lower yield, so that some. thing more than two acres was needed to feed the average Englishman. But the German dietary was much simpler: it contained less meat, less butter and sugar, fewer eggs, less fruit; all these desirable and luscious things were replaced by potatoes, of which the Germans consumed twice as much as we did in Great Britain. Their dietary required less land for its production, and one acre almost sufficed to feed the average German. As they were less densely packed on the land than we are, they were able to produce nearly 85 per cent of their food.

The necessities of war are driving us on to the German dietary : our average consumption of meat -including all sources - is now estimated at about $70 \mathrm{lb}$. per head per annum-half our pre-war consumption : so that the area of land required for our present dietary is considerably less than it was.

In pre-war times we imported into Great Britain more than 60 per cent of our food, but the import was not evenly distributed. British farmers concentrated on the most lucrative products; they produced the whole of our milk and our potatoes, some 70 per cent or more of our eggs, poultry and malting barley, 50 per cent of all our meat-a much higher proportion of the best-quality meat-Dut only 25 per cent of our wheat and only 10 per cent of our butter, these being much less lucrative in British conditions. Our pre-war"feeding arrangements gave a higher standard of living not only to the people in the towns but also to the farmers and farm workers than the German system. The annual net value of the output of the British farm workers was, before the War, put at $£ 200$, while that of the German farm worker was only $£ 70$; the average weekly wage for the British worker was 30-36s. and was rising, while that of the German was 23s. German farm workers had to work at least as hard as ours, but their products were less lucrative and so their remuneration was lower.

The choice before Europe after the War will be self-sufficiency, or high standards of nutrition. In a self-sufficing Europe the inhabitants restrict themselves to what they can produce and go without the rest, or accept instead products for which one must use the German name Ersats because the English language does not possess a sufficiently disagreeable word. Already the Germans have re-organized agriculture in the occupied countries on this basis, aiming at calories rather than protective foods. Grain and potatoes have replaced the more specialized and lucrative live-stock products and fruit of the western countries, Holland, Belgium and Denmark, bringing great distress on their farmers. If this were continued 
after the War it would impoverish not only Europe but the primary producers also. Even prior to the War there was considerable over-production of calories in relation to the demand, and this had led to such pitiful results as the burning of wheat in some regions, while others, for example Italy, were suffering from shortages which a policy of self-sufficiency forbade them to satisfy. Representatives of the occupied countries now in Great Britain have expressed their views at conferences of the British Association, Chatham House and elsewhere; they reject the idea of a self-sufficing Europe; they do not want this low standard of life and they recognize that it leads to chaos, even to war. They prefer to aim at the highest possible standard of nutrition : the phrase 'freedom from want' has reverberated through Europe, and aroused among its stricken people hopes and desires that we, who have never suffered as they, can only dimly apprehend. But this policy of abundance means that each region must produce the foods it can grow best, and exchange its products freely with other regions : there is no place for restrictions on trade in food. It is, in fact, the old policy of 'peace and plenty' that Bright and Cobden advocated so long ago.

If this were adopted, the farmers of Europe would aim at producing high-quality protein and protective foods, taking calorie production in their stride but not aiming specifically at it. They would import from the great primary producing regions of the world the additional calories and protein needed for themselves and their animals. After the first year of calorie production their efforts would be diverted to these more profitable activities.

Another decision must also be taken. What is to be the pattern of country life in Europe after the War? Before the War, most of Europe's agricultural land was in small holdings, though there were large estates in Poland, Hungary and elsewhere. Russia, on the other hand, has gone in for large farms. In commerce and industry the large unit has obvious advantages and has in fact eliminated many of the smaller producers. It has been urged that we now have the chance of reorganizing European agriculture and should do it on the basis of large farms, not of small ones. The analogy between agriculture and industry cannot be pushed far because of the fundamental distinction that the processes of industry are wholly under control and can be worked to a programme, while those of agriculture are not: there must on each farm be daily adaptation of programme to weather and other conditions. We have had some very successful large farms, but it has not infrequently happened that when the leading spirit has departed, they break up again into smaller units. Prof. A. W. Ashby recently analysed the returns from a number of farms and showed that the small farms gave a greater return per acre and per $£ 100$ expended, employed more men per 100 acres and paid more in wages than the large ones. Actually the case is not as simple as it looks, and the figures need a good deal of qualification: probably the safest generalization is that small farms are best for gross production; large farms for net production.

There would, of course, be a strong case for large farms if Europe were adopting the New Order and going in widely for grain production, this being well adapted to big-scale operations and to heavy mechanization. But the production of protective foods, involving as it does numbers of animals of various kinds, is well suited to the small farm.
A combination of the two systems, large and small, has been worked out in the collective farms of the U.S.S.R. The grain and large cultures are done on the large scale; the farm may be 2,000 or more acres in size and the workers share the produce-or, rather, what is left of it after Government and other dues are paid, the sharing being in accordance with the work done. But in addition, each member of the collective has his own piece of land and his own animals : actually a considerable number of the farm animals of the U.S.S.R. belong to the peasants as their own individual property. The conditions favour the system: the large rolling plains of the south are eminently suited to grain production; the large areas of land not yet utilized prevent any possibility of population pressure on the land, while the high density of population on the farms affords scope for working the individual holdings and tending the privately owned livestock. These conditions, however, do not obtain in any of the European countries.

Representatives of the occupied countries have stated very clearly that they do not want large farms, whether privately owned, State owned, or collective. They admit that some of their large farms have been very productive; some of the Polish estates, for example, have been not only efficient producers but also their homes have been delightful centres of Polish life and culture. But the majority prefer the smaller holdings. So agrarian reform has for some years been busy breaking up these big estates into small peasant holdings. Even where the management has thereby become less efficient, the social advantages are considered to outweigh the economic disadvantages. There is a big peasant population for which provision must be made. Industry is not far enough advanced to absorb large numbers, and emigration is probably out of the question. Also, there is very real land hunger; the innate desire to own a piece of land-usually a particular piece of land. In eastern Europe this has even become a line of political cleavage, and strong Peasant Parties exist in Poland, Czechoslovakia, Jugoslavia and elsewhere.

The history of collectivization in the U.S.S.R. is a clear warning against forcing on the peasants any scheme of amalgamation that they do not like. For the first few years of collectivization the numbers of animals fell drastically : there were several causes, but one was the dislike of some of the peasants for the new scheme. Then came the compromise in 1935 and 1936, which allowed the peasants their own bit of land and their own animals, and the numbers of animals began to go up: unfortunately the War came before one could see the full results. We could not, however, tolerate the possibility of peasant disturbances in Europe after this War, and so we must accept the decision to re-establish small peasant farms.

But they need not reproduce the technical and economic weaknesses of the old ones. All the countries concerned have set up agricultural research, advisory and educational services, and the small farmer can be given all the advantages of better varieties of crops, more efficient fertilizers, more economical rations for his livestock, better health services for animals and for crops. Further, agricultural engineers are now turning their attention to the design and manufacture of small implements suitable for small farms that will not only lighten the work but also enable it to be done much more quickly, so avoiding many of the wastes and losses 
resulting from slower methods. Electricity and the internal combustion engine have the great advantage that they are little less economical for a small job than for a large one. The small farmer need be neither inefficient nor a drudge ; he can be technically competent and provided with labour-saving implements.

In the past, the financing of the farm and the buying and selling of the produce have been major difficulties in the life of the peasant. The moneylender and the middleman-whether they were one and the same or different individuals-have often made the peasants' life a burden. Marketing of produce has always been a wasteful procedure; the bulky material has been sold to a middleman and the small stuff taken by the women to market and there sold for whatever it would fetch-a timeconsuming operation which, however, was very sociable and clearly enjoyed by the women. These and many other difficulties can be got over by cooperation, and I am firmly of opinion that the only hope of successful establishment of peasant holdings lies in the development of a strong cooperative movement. The Horace Plunkett Foundation in Great Britain is a mine of information on the subject; Denmark can show actual working models, and indeed most of the occupied countries have some experience with it. Co-operative societies can not only buy for the peasant, finance useful operations and warn severely against useless ones ; they can also take over the peasants' products, grade and process them, pack them properly and sell them through expert: salesmen who know the best markets and can obtain the highest prices. They can thus assure to the peusant the maximum return for his labour.

The experience of Denmark shows how well cooperation can flourish in an educated community. Education is absolutely essential ; not simply technical education, but, what is even more important, the moral education that teaches a man to pull his weight and play the game; to accept his full share of responsibility for the community, doing the right thing because it is right and not simply because he fears he might otherwise be caught. In addition to agricultural schools, the Danes early set up 'Folk High Schools' to give this moral training to awaken intelligence and idealism; they were Christian, national institutions and they helped to form an industrious, honest, competent farming community composed of extremely hard-working people, producing commodities of high quality and enjoying a standard of life that was the envy of most of Europe. The Danish small farm expresses the ideal at which many of the leaders of the occupied countries are looking with longing eyes, hoping that when their long night of agony is ended there may dawn a brighter day for themselves and their children.

We, too, shall have our part to play. In his extremely interesting "Life" of Marlborough, Mr. Churchill shows how in the seventeenth and eighteenth centuries Great Britain twice saved Europe by heading the Allied Nations against a power seeking to dominate the whole Continent. Twice the war was won, but twice the peace was lost because we withdrew too soon. Modern history has made the lesson more emphatic; nations cannot live in isolation. On all grounds-economic, political and moral-we must in the reconstruction of Europe render all possible help and continue to play our part in the years of peace to which the nations are looking forward with such ardent longing.

\section{EDUCATION IN THE BRITISH ARMY}

\author{
BY LIEUT. T. H. HAWKINS
}

$T$ WO and a half years ago the British Army education scheme as we know it to-day was officially launched as the "greatest experiment in adult education that has been undertaken in this country". During its period of growth the scheme has come in for a great deal of publicity, adverse and otherwise. A review of its progress may be of use in helping to assess its value as an indication of the way in which adult education is likely to develop in Great Britain in future years.

In the months preceding the outbreak of war the Workers Educational Association and the Y.M.C.A., in consultation with the Board of Education, had convinced the War Office that educational opportunities of a general character, apart from any classes and lectures which form part of military training, should be provided for the young militiamen during their six months compulsory training. To meet the potential demands for lecturers, the universities enlarged their extra-mural boards ad hoc by adding to the representation of the voluntary bodies concerned and began to lay plans for their active participation in the scheme. War came, and these ad hoc committees were dispersed.

But the demand for education could not be ignored. In the early part of 1940, the initiative of the various voluntary organizations connected with adult education led to a widely representative conference at which the setting up of a Central Advisory Council for Adult Education in H.M. Forces was decided upon. In due course the universities, local education authorities and voluntary organizations for adult education appointed members, the three Services nominating observer representatives. The vicechancellors of universities and principals of university colleges were invited to call conferences in their areas, for the purpose of establishing regional committees through which the Central Advisory Council might work. Thus the civilian educational resources were mobilized and placed at the disposal of the Services.

Later a committee met under Sir Robert Haining to consider means whereby the Army's own resources for lecturing and teaching, as well as organization and administration, might be established. (Here it may be noted that, at the outbreak of war, the personnel of the Army Educational Corps of the Regular Army were transferred to operational roles, for the discharge of which in France they were officially commended by Lord Gort in his dispatches.) The report of the Haining Committee appeared in August 1940 , and it is from that date that the scheme as it now exists may be said to have had its birth.

A directorate of Army education was established, the first director being Mr. F. W. D. Bendall, who was seconded from the Board of Education. The Army Education Corps was gradually strengthened, both by the return of its regular peace-time personnel and by the inclusion of new members from the wartime Army.

The objects of the scheme can be briefly stated : (1) maintaining the men and women of the Army in good heart and morale by the provision of educational activities which could be pursued in their off-duty hours ; (2) improving the military efficiency of the fighting services directly by the sharpening of mental 